\title{
PATENT HEIGHT AND COMPETITION IN PRODUCT IMPROVEMENTS
}

by

Theon van Dijk

\section{MERIT Research Memorandum 2/94-015}

MERIT Research Memoranda can be ordered from the address below, or be obtained in electronic form (Postscript) by anonymous ftp at meritbbs.rulimburg.nl

Revised Version, April 1994

\section{ABSTRACT}

The stringency of novelty requirements that patent offices and courts use in judging infringement issues and patentability of inventions defines the height of protection provided to a patentholder. In this paper the effects of patent height are studied in a duopoly where firms compete in product improvements. Minimal steps of improvements, determined by the height, limit the strategy space of competitors who want to invent around a patent. It is shown that low patents do not affect the natural market equilibrium. A patentholder can lose with medium patent heights, but he becomes a pure monopolist if patents are high. The nonpatentholder can gain with medium heights but is increasingly worse off with higher patents. (JEL Code L19, L43, O34)

* This research was sponsored by the Foundation for the Promotion of Research in Economic Sciences, which is part of the Netherlands Organization for Scientific Research (NWO). I thank, without implicating, Patrick Van Cayseele, Claude Crampes, Paul David, Daniel Deneffe, Reinoud Joosten, Eric de Laat and Luc Soete and two anonymous referees for helpful comments.

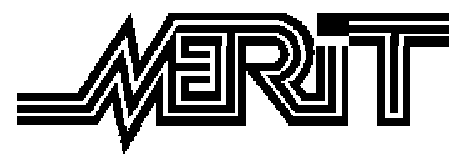

Maastricht Economic Research Institute on Innovation and Technology University of Limburg, P.O. Box 616, NL-6200 MD Maastricht, The Netherlands tel (31) (0)43 883869, fax (31) (0)43 216518, Email Merit.Frontdoor@Merit.Rulimburg.nl 


\section{Introduction}

Empirical studies on the appropriability of inventions (e.g., Mansfield et al. (1981), Levin et al. (1987), Griliches (1990)) provide evidence that patent protection is limited. Many opportunities are left open for competitors to invent around patents. One can therefore hardly claim, as is commonly done, that patents provide pure monopoly power. They restrict at most the opportunities for inventing around. The legal profession is far more aware of this fact. ${ }^{1}$ Lawyers are often confronted with the imperfectness of patent protection as the considerable amount of case law from patent disputes demonstrates (e.g. Cornish (1989) as a leading textbook on intellectual property).

Until recently, theoretical economists have hardly taken into account the economic and legal practice of patent protection. Nordhaus' (1969) seminal work on patent length, for example, assumes perfect protection during the lifetime of the patent. The same assumption is also implicitly present in most models of technological competition where the first firm that generates an invention gets a patent and takes all the profits, leaving the loser of the race no chances whatsoever (for an overview of patent races, see Reinganum (1989). Recent contributions aim at relaxing the assumption of perfect protection (Gilbert and Shapiro (1990), Klemperer (1990)). These studies allow for imitations beside the patent, provided that these imitations are not too similar. When substitutes in the form of imitations are less similar to the patented product, the monopoly power of a patentholder increases. Gilbert and Shapiro are therefore able to define the breadth of patent protection rather generally as the ability of the patentholder to raise price. Their focus is on the socially optimal mixture between patent length and breadth. Klemperer defines patent breadth more explicitly within a model of horizontal product differentiation, as an interval where no competitors are allowed. The usage of a model of horizontal differentiation turns out to yield richer conclusions about the optimal mixture, reproducing and extending those of Gilbert and Shapiro.

In this paper, I focus on the height of patent protection. Patent height is mainly determined by the stringency of the novelty requirements used by examiners in the patent office. Most patent laws dictate that an invention is only patentable if it is non-obvious and involves an inventive step. These conditions are certainly satisfied for the small group of fundamental

\footnotetext{
${ }^{1}$ Cornish (1989, p.18) even states: "To the extent that intellectual property is capable of generating market power, it offers its owner (and his associates) the opportunity to reduce output and raise prices. What it does not bring about is the condition in which the monopolist behaves as though he were the only competitor on the market. Yet the more naive arguments in favour of one or other exclusive right often imply that this alone will be the effect of according the right sought."
} 
inventions. But the judgement on patentability is more difficult when improvements of existing products are concerned. When is an improvement obvious and how much inventivity is required? It is the task of patent examiners to define the bounds of patentability and infringement of current patents. The central question in this paper is how the height of patent protection affects the competition in product improvements in a duopoly where one firm holds a patent, which restricts the strategy set of the other.

Before stressing why the distinction between patent height and breadth is important, let me first explain the difference. Whereas breadth is defined as the extent of protection against imitations, height indicates the protection against improvements. In terms of product characteristics, one could say that height defines the minimal number of new elements which an invention must contain, whereas breadth defines the maximum number of elements which are allowed to be imitated. Suppose a patented product is made up of $v$ elements. Think, for example, of technical attributes like materials, design, electronics schemes, etc., which define the invention in a unique way. Protection height then indicates how many new elements $h$ are required in order not to infringe an ongoing patent. Breadth defines the maximum number $b$ out of the $v$ that is allowed to be imitated without infringing.

The difference between imitations and improvements can be found on both the cost side and the demand side. Although imitations may also require investment in R\&D in order to obtain learning and imitation capabilities (Cohen and Levinthal (1989)), improvements are likely to cost more R\&D because new information has to be generated. With regard to the demand side, as previously explained, Klemperer (1990) treats imitations as horizontal differentiations of the patented product. Consumers do not agree on the most preferred variety. Some consumers prefer protected varieties, while others prefer imitations outside the protected interval. Improvements are basically different from imitations in this respect. Improvements can be considered as vertical differentiations. It is reasonable to expect that, at equal prices, all consumers prefer an improvement to an older version of the product. Patent height can then be thought of as defining a protected region on the vertical product spectrum. Competitors that enter the market are restricted in their choices of improvement. They must generate a minimum level of improvement in order not to infringe the current patent. ${ }^{2}$ The dimensions of breadth and height thus define protection against two different types of competition; one resulting from horizontal differentiation and another resulting from vertical differentiation. These two types of competition have a differential impact on the patentholder.

\footnotetext{
2 The literature on minimum quality standards also uses vertical differentiation models (e.g., Ronnen (1991) and Crampes and Hollander (1991)). The major difference with the analysis presented here is that only the non-patentholder is restricted in my model whereas in the other models mentioned both firms are restricted.
} 
The effect of vertical differentiation is that it relaxes price competition; therefore firms have a tendency to differentiate their products maximally (Shaked and Sutton (1982)). Horizontal differentiation may have an opposite effect. At least for linear transport costs, as in the original Hotelling (1929) analysis, firms differentiate minimally.

Taking these cost and demand features into account, two basic strategies for inventing around a patent can be distinguished: an imitation strategy "aside" the patented product and an improvement strategy "above" it. An example may clarify the two possible strategies. Klemperer (1990, p. 114) mentions the patent of Prince Manufacturing on the oversized tennis racket. The breadth of protection is known to run from 85 to 130 square inches rackets. A competitor pursuing an imitation strategy can only enter with a similar racket outside this protected range. But there is also another possibility, not examined by Klemperer. A competitor can improve a racket inside the range in such a way that it satisfies patent examiners. For example, a 100 square inches racket can be made stiffer by the use of a new fibre or a better design. Both cost and demand properties can play an important role in choosing the appropriate inventing-around strategy. An imitation strategy has a relative cost advantage but may be more severely restricted by patent breadth because, being a horizontal differentiation, the imitation may be chosen close to the patented product. A competitor that pursues an improvement strategy has a natural tendency to create distance away from the patent, but this tendency may be suppressed by high R\&D costs. The impact of the imitation strategy on the patentholder's profits has been examined in the above mentioned models of patent breadth. So far, however, the impact of the improvement strategy has not been analyzed.

This paper will concentrate on the effects of novelty requirements once a patent is granted. Scotchmer and Green (1990) have analyzed a related problem. They discuss the social tradeoff that occurs in setting the novelty requirements when firms apply for patents. Novelty requirements appear to have a dual character. They determine the coverage of granted patents - the study object of this paper -, but they also affect the stage of R\&D competition before the patent is possibly granted. This second aspect is studied in Scotchmer and Green (1990). The main benefit of weak novelty requirements then is that technical information becomes public at an earlier date so that other firms can build further on it sooner. However, weak requirements may also induce the inventor to withhold his invention, thereby keeping the lead, and aim at a more profitable invention later on. Strong novelty requirements reduce the amount of wasteful duplicative R\&D by inducing firms that have fallen behind to drop out of the race. In order to focus fully on the extent of protection, I will omit the stage of R\&D competition here. 
The plan of this paper is as follows. In section 2, a model is constructed which is based on the idea of improvements being vertical differentiations of a new product. First, I examine the competition in product improvements in the absence of patents. In section 3, I will analyze the effects of patent height on the competition in product improvements. In a nutshell, the major conclusions are that low patent heights do not affect the natural market equilibrium without patents, medium heights can be favourable and unfavourable for the patentholder, and high patents provide pure monopoly power. Conclusions and possible applications are presented in section 4 .

\section{The Model}

The starting point of the analysis is the appearance of a basic invention. In this section, I assume that this basic invention is public property. The basic invention is so raw that no consumer is prepared to buy it. Consumers can only extract surplus from the basic invention if it is further developed. Defining the demand side more precisely, the net surplus $U$ of an individual consumer is given by the following (indirect) utility function:

$$
\mathrm{U}= \begin{cases}\mathrm{mv}-\mathrm{p} & \text { if the consumer buys } \\ 0 & \text { otherwise }\end{cases}
$$

where $\mathrm{v} \in[0, \infty\rangle$ is the degree of improvement (with the basic invention given by $\mathrm{v}=0$ ), $\mathrm{p}$ is the price of improvement $\mathrm{v}$ and $\mathrm{m}$ is a parameter indicating the intensity with which a consumer prefers improvements. The parameter $\mathrm{m}$ is uniformly distributed with density 1 on $[b-1, b]$, where $1<b<2$. A consumer only buys if he gets a non-negative net surplus. Each consumer decides in each period whether or not to buy (one unit). The utility function (1) is standard in the literature on vertical differentiation (e.g. Shaked and Sutton (1982)). Applying function (1) in the context of technical change is justified because consumers are expected to evaluate product improvements in much the same way as qualities of a product. Consumers prefer large to small improvements, just like they prefer high to low-quality products.

There are two firms, 1 and 2, potentially entering the new market with improvements of the basic invention. Each of the firms is assumed to offer one improvement at the most. There are two motivations behind this assumption. First, the diversity of consumers' tastes (given by the range of $\mathrm{m}$ ) is chosen such that there is only room at the market for two improvements. Competition analysis then requires that each of the two firms has one improvement at the most. Second, it is true that in business practice one can often observe that a firm does not have one patent but a number of related patents, all in the same 
technical field. But even such a cluster of patents cannot provide perfect protection. Competitors can still invent around the cluster. Essentially we are then back at the scenario studied in this paper: one firm has a patent (or a cluster of patents) and another firm enters the market with an improvement (of the most advanced patent of the cluster). Once chosen, I assume that an improvement cannot be changed. As we will see below, there are circumstances under which it would be beneficial for a firm to lower its improvement level. However, high fixed costs associated with each improvement are assumed to prevent this. The competition between both firms takes place in two stages. In the first stage, each firm decides whether or not to enter the market and which improvement to choose. Knowing which decisions are made in the first stage, each firm then chooses a price strategy. This sequence reflects the fact that price decisions are more flexible than improvement and entry decisions. The solution concept that I employ for this two-stage model is the subgame perfect equilibrium. It can be obtained by backward induction. First, I will determine the Nash equilibrium in pricing strategies of the second stage. In the second stage, I will determine the equilibrium strategies in product improvements and entry. Only pure strategies are considered.

It is assumed here that both firms are characterized by the same R\&D cost structure, which is kept as simple as possible. There are no development costs involved in the generation of improvements. It only costs time. Starting at time 0 , firm i introduces $\mathrm{v}_{\mathrm{i}}$ in period $\mathrm{T}_{\mathrm{i}}$, where $\mathrm{T}_{\mathrm{i}}=\alpha \mathrm{v}_{\mathrm{i}}$, for $\mathrm{i} \in\{1,2\}$ and $0 \leq \alpha \leq 1$. The profit that is lost because of a later introduction time is the real development cost. If both firms enter the market, the first-stage subgame is defined by a pair of improvements $\left\{\mathrm{v}_{\mathrm{S}}, \mathrm{v}_{\mathrm{L}}\right\}$, such that $\mathrm{v}_{\mathrm{S}} \leq \mathrm{v}_{\mathrm{L}}$. The subscript $\mathrm{S}$ denotes the firm that has developed an improvement that is smaller than the other improvement. The other firm has the larger improvement and is denoted by subscript L. Note that each firm can develop either the small improvement or the large improvement. Assuming that both firms start their development in the same period, $\mathrm{v}_{\mathrm{L}}$ is always introduced later than $\mathrm{v}_{\mathrm{S}}$. As a consequence, the market structure can change over time. The firm with $\mathrm{v}_{\mathrm{S}}$ will enter in period $\mathrm{T}_{\mathrm{S}}$. It then has a temporary monopoly position and sets a monopoly price, denoted by $\mathrm{p}_{\mathrm{M}}$. This monopoly will last until the other firm enters at $\mathrm{T}_{\mathrm{L}}$ with $\mathrm{v}_{\mathrm{L}}$. From $\mathrm{T}_{\mathrm{L}}$ until a doomsday $\mathrm{J}$ the market structure then will be a duopoly. By assumption, the former monopolist can only react to the entrant by setting a new price, denoted by $\mathrm{p}_{\mathrm{S}}$, as a function of the entrant's price $\mathrm{p}_{\mathrm{L}}$. Assuming that all consumers are price and improvement takers, during monopoly each consumer has the choice between buying $\mathrm{v}_{\mathrm{S}}$ at price $\mathrm{p}_{\mathrm{M}}$ or not buying at all. Consumer choices extend when the later firm introduces $\mathrm{v}_{\mathrm{L}}$ at $\mathrm{T}_{\mathrm{L}}$. Each consumer can then choose to buy $\mathrm{v}_{\mathrm{S}}$ at price $\mathrm{p}_{\mathrm{S}}, \mathrm{v}_{\mathrm{L}}$ at price $\mathrm{p}_{\mathrm{L}}$, or none of the improvements. 


\subsection{Price Competition}

The following demand function is relevant in two cases. First, in the scenario in which only one firm enters the market and remains a monopolist until doomsday J. Second, during the period when the small improvement firm is alone in the market and the other firm has not entered yet.

$$
\mathrm{D}\left(\mathrm{p}_{\mathrm{M}}\right)=\mathrm{b}-\mathrm{p}_{\mathrm{M}} / \mathrm{v}_{\mathrm{S}}
$$

for $p_{M} / v_{S}>b-1$. Without affecting the basic results, I assume that the unit production costs are zero. It can be shown that the monopoly price and profit per period are $\mathrm{p}_{\mathrm{M}}{ }^{*}=\mathrm{bv}_{\mathrm{S}} / 2$ and $\pi_{S}\left(p_{M}^{*}\right)=b^{2} v_{S} / 4$. The lower market segment $[b-1, b / 2]$ is not served.

Now consider the demand functions in case of duopoly. The consumer who is indifferent during duopoly as to the small and large improvement is given by the preference parameter $\mu=\left(p_{L}-p_{S}\right) /\left(v_{L}-v_{S}\right)$. The firm with $v_{S}$, which charged $p_{M}$ before, now changes its price and charges $\mathrm{p}_{\mathrm{s}}$. For computational ease, I assume that the market is served completely during duopoly. I take $\left(\mathrm{v}_{\mathrm{S}}+2 \mathrm{v}_{\mathrm{L}}\right) /\left(2 \mathrm{v}_{\mathrm{S}}+\mathrm{v}_{\mathrm{L}}\right)<\mathrm{b}<2$. $^{3}$ The demand functions are then:

$$
\mathrm{D}_{\mathrm{S}}\left(\mathrm{p}_{\mathrm{S}} ; \mathrm{p}_{\mathrm{L}}\right)=\mu+1-\mathrm{b}, \quad \mathrm{D}_{\mathrm{L}}\left(\mathrm{p}_{\mathrm{L}} ; \mathrm{p}_{\mathrm{S}}\right)=\mathrm{b}-\mu
$$

The Nash equilibrium prices are $\mathrm{p}_{\mathrm{S}}^{N}=(2-\mathrm{b})\left(\mathrm{v}_{\mathrm{L}}-\mathrm{v}_{\mathrm{S}}\right) / 3$ and $\mathrm{p}_{\mathrm{L}}{ }^{N}=(\mathrm{b}+1)\left(\mathrm{v}_{\mathrm{L}}-\mathrm{v}_{\mathrm{S}}\right) / 3$, with associated profits of $\pi_{\mathrm{S}}\left(\mathrm{p}_{\mathrm{S}}{ }^{N} ; \mathrm{p}_{\mathrm{L}}{ }^{N}\right)=(2-\mathrm{b})^{2}\left(\mathrm{v}_{\mathrm{L}}-\mathrm{v}_{\mathrm{S}}\right) / 9$ and $\pi_{\mathrm{L}}\left(\mathrm{p}_{\mathrm{L}}{ }^{N} ; \mathrm{p}_{\mathrm{S}}{ }^{N}\right)=(\mathrm{b}+1)^{2}\left(\mathrm{v}_{\mathrm{L}}-\mathrm{v}_{\mathrm{S}}\right) / 9$ (see Tirole (1988) for an elaboration).

\subsection{Competition in Product Improvements}

First, I will examine the pure monopoly scenario, where the monopoly position lasts from the introduction time until the doomsday J. The monopolist will have profits $\pi_{\mathrm{S}}\left(\mathrm{p}_{\mathrm{M}}{ }^{*}\right)$, as determined above. The profit function of such a monopolist in the first stage is:

$$
\pi_{\mathrm{S}}\left(\mathrm{v}_{\mathrm{S}}\right)=\left(\mathrm{J}-\mathrm{T}_{\mathrm{S}}\right) \pi_{\mathrm{S}}\left(\mathrm{p}_{\mathrm{M}}^{*}\right)
$$

In order to keep the analysis as simple as possible, I assume that pay-offs are not discounted. A similar effect originates from the doomsday $\mathrm{J}$, when everything ends. The monopolist is confronted with the following trade-off: on the one hand, his profit per period increases if he develops a larger improvement, but on the other hand, it costs more development time

\footnotetext{
${ }^{3}$ This condition turns out to be always possible in the analysis to follow. All equilibrium values of $\mathrm{v}_{\mathrm{S}}$ and $\mathrm{v}_{\mathrm{L}}$ fulfill the condition that $1<\left(\mathrm{v}_{\mathrm{S}}+2 \mathrm{v}_{\mathrm{L}}\right) /\left(2 \mathrm{v}_{\mathrm{S}}+\mathrm{v}_{\mathrm{L}}\right)<2$.
} 
so that there will be less time to capitalize on his investments. The next step is to calculate the optimal improvements as a function of each other, given the equilibrium prices determined above. After substitution of the time cost structure $T_{S}=\alpha v_{S}$ and the optimal profit $\pi_{\mathrm{S}}\left(\mathrm{p}_{\mathrm{M}}{ }^{*}\right)$ in (4), the optimal improvement of the monopolist can simply be determined as $\mathrm{v}_{\mathrm{S}}{ }^{*}=\mathrm{J} / 2 \alpha$, with the associated optimal profits of $\pi_{\mathrm{S}}\left(\mathrm{v}_{\mathrm{S}}^{*}\right)=\mathrm{b}^{2} \mathrm{~J}^{2} / 16 \alpha$. The optimal improvement $\mathrm{v}_{\mathrm{S}}{ }^{*}$ increases if the monopolist is given more time (later $J$ ) and if the development costs are lower (smaller $\alpha$ ). The optimal monopoly profit $\pi_{\mathrm{S}}\left(\mathrm{v}_{\mathrm{S}}^{*}\right)$ also increases if the demand properties are more favourable; a higher $b$ means that improvements are more valued by consumers.

When two firms enter the new market, the profits of the firm with $\mathrm{v}_{\mathrm{S}}$ contain monopoly profits, gained from $\mathrm{T}_{\mathrm{S}}$ until $\mathrm{T}_{\mathrm{L}}$, and duopoly profits, from $\mathrm{T}_{\mathrm{L}}$ until doomsday $\mathrm{J}$ :

$$
\pi_{\mathrm{S}}\left(\mathrm{v}_{\mathrm{S}} ; \mathrm{v}_{\mathrm{L}}\right)=\left(\mathrm{T}_{\mathrm{L}}-\mathrm{T}_{\mathrm{S}}\right) \pi_{\mathrm{S}}\left(\mathrm{p}_{\mathrm{M}}{ }^{*}\right)+\left(\mathrm{J}-\mathrm{T}_{\mathrm{L}}\right) \pi_{\mathrm{S}}\left(\mathrm{p}_{\mathrm{S}}{ }^{N}\right)
$$

The profit function of the firm that enters later at $T_{L}$ with $v_{L}$ is:

$$
\pi_{\mathrm{L}}\left(\mathrm{v}_{\mathrm{S}} ; \mathrm{v}_{\mathrm{L}}\right)=\left(\mathrm{J}-\mathrm{T}_{\mathrm{L}}\right) \pi_{\mathrm{L}}\left(\mathrm{p}_{\mathrm{L}}{ }^{N}\right)
$$

Before proceeding further, I want to emphasize some important properties of the profit functions (5) and (6). The profit per period $\pi_{S}\left(p_{M}^{*}\right)$ in equation (5) increases in $v_{S}$. This property was already mentioned above in the pure monopoly case. In order to simplify the notation, let $\mathrm{q} \equiv \mathrm{b}^{2} / 4$, so that $\pi_{\mathrm{S}}\left(\mathrm{p}_{\mathrm{M}}{ }^{*}\right)=\mathrm{qv}_{\mathrm{S}}$. The duopoly profits per period $\pi_{\mathrm{S}}\left(\mathrm{p}_{\mathrm{S}}{ }^{N}\right)$ and $\pi_{\mathrm{L}}\left(\mathrm{p}_{\mathrm{L}}{ }^{N}\right)$ decrease in $\mathrm{v}_{\mathrm{S}}$ for the small improvement firm (5) as well as the large improvement firm (6). This property is well known in the vertical product differentiation literature and is the result of more relaxed price competition as products are more differentiated (Shaked and Sutton (1982)). It can also be found in the way profits behave in $\mathrm{v}_{\mathrm{L}}$. Since a larger $\mathrm{v}_{\mathrm{L}}$ means a larger distance between both improvements, the profits per period increase for both firms. Define $\mathrm{r} \equiv(2-\mathrm{b})^{2} / 9$ and $\mathrm{s} \equiv(\mathrm{b}+1)^{2} / 9$, so that $\pi_{\mathrm{S}}\left(\mathrm{p}_{\mathrm{S}}{ }^{N}\right)=\mathrm{r}\left(\mathrm{v}_{\mathrm{L}}-\mathrm{v}_{\mathrm{S}}\right)$ and $\pi_{\mathrm{L}}\left(\mathrm{p}_{\mathrm{L}}{ }^{N}\right)=\mathrm{s}\left(\mathrm{v}_{\mathrm{L}}-\mathrm{v}_{\mathrm{S}}\right)$. For the values of $b$ which are taken here it holds that $s>q>r$. This ranking will turn out to be important further on.

After substitution of the introduction times and the profits in the second stage in the profit functions (5) and (6), the following improvement reaction functions can be derived:

$$
\begin{aligned}
& \mathrm{v}_{\mathrm{S}}^{*}\left(\mathrm{v}_{\mathrm{L}}\right)=\mathrm{v}_{\mathrm{L}}(\mathrm{q}+\mathrm{r}) / 2 \mathrm{q}-\mathrm{rJ} / 2 \alpha \mathrm{q} \\
& \mathrm{v}_{\mathrm{L}}^{*}\left(\mathrm{v}_{\mathrm{S}}\right)=\mathrm{v}_{\mathrm{S}} / 2+\mathrm{J} / 2 \alpha
\end{aligned}
$$


where $\mathrm{v}_{\mathrm{S}}, \mathrm{v}_{\mathrm{L}} \in[0, \mathrm{~J} / \alpha]$. An important property of (7a) is that it implies that $\pi_{\mathrm{S}}$ increases monotonically in $\mathrm{v}_{\mathrm{S}}$ along the reaction curve. This can be checked by substituting (7a) into (5) and taking the first derivative of $\pi_{S}$ with respect to $v_{S}{ }^{*}$, which turns out to be positive. The intuition behind this is the following. If $\mathrm{v}_{\mathrm{L}}$ increases, $\mathrm{v}_{\mathrm{S}}{ }^{*}$ also increases, but by less (since $(\mathrm{q}$ $+r) / 2 q<1$ ). The number of monopoly periods as well as the monopoly profit per period increase. The profit per period in duopoly also increases because the distance between $\mathrm{v}_{\mathrm{L}}$ and $\mathrm{v}_{\mathrm{S}}$ becomes larger. These positive effects on $\pi_{\mathrm{S}}$ outweigh the only negative effect of a smaller number of periods before doomsday. The opposite holds for the firm with the large improvement; $\pi_{\mathrm{L}}$ decreases monotonically in $\mathrm{v}_{\mathrm{L}}$ along the reaction curve $(7 \mathrm{~b})$. The intuition is simple. Suppose $\mathrm{v}_{\mathrm{S}}$ increases. As a consequence, $\mathrm{v}_{\mathrm{L}}{ }^{*}$ will increase but only by half as much, so that the distance between both improvements becomes smaller. Considering, in addition, that the remaining time before doomsday shrinks, it is clear that $\pi_{\mathrm{L}}$ decreases.

The Nash equilibrium in the first stage of competition in product improvements can be found by solving the reaction functions $(7 \mathrm{a})$ and $(7 \mathrm{~b})$ simultaneously for $\mathrm{v}_{\mathrm{S}}$ and $\mathrm{v}_{\mathrm{L}}$. Define this solution as the basic Nash equilibrium $\left\{\mathrm{v}_{\mathrm{S}}{ }^{N}, \mathrm{v}_{\mathrm{L}}{ }^{N}\right\}$, given by:

$$
\begin{aligned}
& \mathrm{v}_{\mathrm{S}}^{N}=\mathrm{J}(\mathrm{q}-\mathrm{r}) / \alpha(3 \mathrm{q}-\mathrm{r}) \\
& \mathrm{v}_{\mathrm{L}}^{N}=\mathrm{J}(2 \mathrm{q}-\mathrm{r}) / \alpha(3 \mathrm{q}-\mathrm{r})
\end{aligned}
$$

Between $T_{S}$ and $T_{L}$, the upper segment of the market $[b / 2, b]$ is served by the temporary monopolist with improvement $v_{S}^{N}$ at a price of $p_{M}^{*}=b J(q-r) / 2 \alpha(3 q-r)$. When the other firm enters in period $T_{L}$ with the large improvement $v_{L}{ }^{N}$, it serves more customers than the monopolist. The upper market segment $[(2 b-1) / 3, b]$ is served at a higher price of $\mathrm{p}_{\mathrm{L}}{ }^{N}=((2 \mathrm{~b}$ - a)Jq) $/ 3 \alpha(3 q-r)$. The small improvement firm now serves the lower market segment $[b-1$, $(2 b-1) / 3]$, which was not served before, at a price of $p_{s}{ }^{N}=((2 b-1) J q) / 3 \alpha(3 q-r)$.

In this basic Nash equilibrium, the overall profit of the firm with the small improvement $\left(\pi_{\mathrm{S}}\left(\mathrm{v}_{\mathrm{S}}{ }^{\mathrm{N}}\right)\right)$ turns out to be positive and lower than that of the firm with the large improvement $\left(\pi_{\mathrm{L}}\left(\mathrm{v}_{\mathrm{L}}{ }^{N}\right)\right): \mathrm{q}^{3} \mathrm{~J}^{2} / \alpha(3 \mathrm{q}-\mathrm{r})^{2}<\mathrm{sq}^{2} \mathrm{~J}^{2} / \alpha(3 \mathrm{q}-\mathrm{r})^{2}$, since $\mathrm{s}>\mathrm{q}$. It is not clear in advance which firm will have the large improvement. There are in fact two basic Nash equilibria in pure strategies. One in which firm 1 has the small improvement and firm 2 has the large improvement $\left\{\mathrm{v}_{1}=\mathrm{v}_{\mathrm{S}}^{N}, \mathrm{v}_{2}=\mathrm{v}_{\mathrm{L}}^{N}\right\}$ and one where this division of roles is reversed $\left\{\mathrm{v}_{1}=\mathrm{v}_{\mathrm{L}}{ }^{N}\right.$, $\left.\mathrm{v}_{2}=\mathrm{v}_{\mathrm{S}}^{N}\right\}$. 


\section{The Effects of Patent Height}

This section studies scenarios where the basic invention is privately owned. One of the two firms, say firm 1, disposes of the basic invention. Two cases are studied: [1] firm 1 cannot keep the basic invention secret, not even for a very short period of time; and [2] firm 1 can keep the basic invention perfectly secret. Any level of the first improvement can be protected by a patent. The patent system under consideration is assumed to be a "first-to-file" patent system ${ }^{4}$. The patent protection is of infinite length and of height $h .{ }^{5}$ It is assumed that the criterion for judging infringement is precise and known by the patentholder and his competitor ${ }^{6}$. The meaning and effects of the patent height $h$ are explained below. It is furthermore assumed that licensing is not possible. Since I want to focus purely on competition aspects, all forms of cooperation are excluded. The impact of excluding licensing will become clear below. To simplify the notation, without affecting the results, I take J = 1 and $\alpha=1$ from now on.

\subsection{Secrecy is Impossible; Patent on the Basic Invention}

In scenario [1], firm 1 is assumed to patent the basic invention immediately (given the lack of secrecy and the first-to-file rule, firm 2 may do so otherwise). I will come back to this assumption below. The technical information in the patent application becomes public and causes both potential entrants to start their development work with the same knowledge level. Hence, there is no asymmetry as far as knowledge is concerned. However, there is asymmetry because firm 1 has a patent on the basic invention and firm 2 has not. The patent is not a barrier to entry that cannot be overcome. It only protects a limited area beyond the basic invention. More precisely, the protection of the patent with height $h$ is the region [0, $\mathrm{h} .^{7}$ The non-patentholder is not allowed to choose his improvement in this region. He has

\footnotetext{
${ }^{4}$ In cases of dispute when two firms claim the same patent, the first-to-file rule says that the firm that filed the application first possibly obtains it. This rule applies in all countries except the US, which applies the "first-to-invent" rule.

${ }^{5}$ Since competitors are assumed to choose an improvement and not an imitation of the patented new product, the breadth of protection is not important here. Case law seems to indicate that the novelty requirements overrule the allowed similarity of imitations (Cornish (1989)). In other words, an identical variety, provided that it is improved sufficiently, is permitted. Mixtures of patent breadth and height as well as optimal strategies for inventing around are studied in Van Dijk (1993).

${ }^{6}$ Waterson (1990) examines a patent system where it is not clear beforehand whether the patentholder or the possible infringer wins in court. This uncertainty may affect the patenting decision.

${ }^{7}$ In their judgement on non-obviousness and inventivity, patent examiners mainly rely on files of former patent applications. The body of knowledge in these files represents to a large extent the (accessible) state of the art, which serves as a benchmark for examination. This is the reason why the protection starts from 0 , i.e. the patented basic invention.
} 
to choose his improvement in the free, not protected region [h, 1].

The second stage of price competition is not affected by the institution of patent heights. The first stage of competition in product improvements, however, can yield different results. Both firms keep on choosing their improvements simultaneously. The strategy space of the nonpatentholder 2 shrinks to $\mathrm{v}_{2} \in[\mathrm{h}, 1]$. The strategy space of firm 1 remains unchanged $\mathrm{v}_{1} \in$ $[0,1]$. This asymmetric effect of patent height is the major difference with the models on minimum quality standards of Ronnen (1991) and Crampes and Hollander (1991). In their models, the minimum standard symmetrically limits the strategy spaces of both firms. With firm 1 holding a patent, each of the firms can still choose the small or large improvement in equilibrium. But we will see that, depending on the height of protection, the improvements can become larger compared to those in the basic Nash equilibria. We will also see that in one category of heights, one basic Nash equilibrium will not occur.

The effects of patent height can be divided into five categories. The two categories for extreme values of $h$ are obvious. Low patents $\left(0 \leq h \leq v_{S}{ }^{N}\right)$ do not affect the basic Nash equilibria. Firm 2 can still have the small improvement without being restricted effectively. In the other extreme category of high patents $(h \geq 1)$, firm 2 does not have enough time to develop an improvement that does not infringe the patent of firm 1 . The patentholder is then assured to have a monopoly position until doomsday 1 and the only improvement that will be on the market is $\mathrm{v}_{1}=1 / 2$. For the medium values $\mathrm{v}_{\mathrm{S}}{ }^{N}<\mathrm{h}<1$, three categories can be distinguished (see Propositions 1.a. and 1.b.). Two categories contain heights for which firm 2 is effectively restricted in the choice of the small improvement (Proposition 1.a.). These heights turn out to be unfavourable for the patentholder if he has the large improvement, because firm 1 loses profit compared to the basic Nash equilibrium. For firm 2, the nonpatentholder, these patent heights are initially favourable.

Proposition 1.a. For $\mathrm{h} \in\left\langle\mathrm{v}_{\mathrm{S}}{ }^{N}, \hat{\mathrm{h}}\right\rangle$ there are two Nash equilibria in pure strategies $(\hat{\mathrm{h}}$ will be defined below): a basic Nash equilibrium with $\mathrm{v}_{1}=\mathrm{v}_{\mathrm{S}}{ }^{N}$ and $\mathrm{v}_{2}=\mathrm{v}_{\mathrm{L}}{ }^{N}$ and a new Nash equilibrium with $\mathrm{v}_{2}=\mathrm{h}$ en $\mathrm{v}_{1}=\mathrm{v}_{\mathrm{L}}^{*}(\mathrm{~h})$. In the new Nash equilibrium (a) both improvements are larger than in the comparable basic Nash equilibrium; (b) the profit of the patentholder 1 decreases in $h$; and (c) the profit of the non-patentholder initially increases and later decreases in $h$. For $h \in\left[\hat{h}, v_{L}^{N}\right]$, the only basic Nash equilibrium is $v_{1}=v_{S}^{N}$ en $v_{2}=v_{L}{ }^{N}$.

Firm 2 is effectively restricted in the choice of the small improvement and not in the choice of the large improvement for the heights $\mathrm{v}_{\mathrm{S}}{ }^{N}<\mathrm{h} \leq \mathrm{v}_{\mathrm{L}}{ }^{N}$. What are the consequences? The one basic Nash equilibrium in which firm 1 has the small and firm 2 has the large improvement remains unchanged. The other basic Nash equilibrium, however, is no longer possible 
because firm 2 is not allowed to enter the market with the improvement $\mathrm{v}_{\mathrm{S}}{ }^{\mathrm{N}}$. The smallest improvement permitted to firm 2 is exactly equal to the height $v_{2}=h{ }^{8}$ Firm 1 will react according to $(7 \mathrm{~b})$ with an improvement $\mathrm{v}_{1}=\mathrm{v}_{\mathrm{L}}{ }^{*}(\mathrm{~h})$. Note that both improvements $\mathrm{h}$ and $\mathrm{v}_{\mathrm{L}}{ }^{*}(\mathrm{~h})$ are larger than in the relevant basic Nash equilibrium with $\mathrm{v}_{2}=\mathrm{v}_{\mathrm{S}}{ }^{N}$ and $\mathrm{v}_{1}=\mathrm{v}_{\mathrm{L}}{ }^{N} ; \mathrm{h}>\mathrm{v}_{\mathrm{S}}{ }^{N}$ holds by definition, and $\mathrm{v}_{\mathrm{L}}{ }^{*}(\mathrm{~h})>\mathrm{v}_{\mathrm{L}}{ }^{N}$ because $\partial \mathrm{v}_{\mathrm{L}}{ }^{*} / \partial \mathrm{v}_{\mathrm{S}}>0$.

The optimal profit of the large improvement firm decreases in $\mathrm{v}_{\mathrm{L}}$ along its reaction curve, as has already been shown in section 2.2.. Hence, if firm 1 has the large improvement, its profit $\pi_{\mathrm{L}}$ decreases in $\mathrm{h}$ for $\mathrm{h} \in\left\langle\mathrm{v}_{\mathrm{S}}{ }^{N}, \mathrm{v}_{\mathrm{L}}{ }^{N}\right]$. This can be seen in figure 1 , where $\pi_{1}{ }^{\prime}$ represents a lower profit level than $\pi_{1}$. Since the firm with the large improvement has the higher profits in basic Nash equilibrium and these profits now decrease in $\mathrm{h}$ for the patentholder, there must be a value for $\mathrm{h}$ where the patentholder collects the same profits with the large improvement as with the small improvement, with firm 2 choosing $v_{S}=h$. Label this critical value for firm 1 as $\hat{h}$, defined as $\pi_{L}\left(\hat{h}, v_{L}{ }^{*}(\hat{h})\right)=\pi_{S}\left(v_{S}^{N}, v_{L}{ }^{N}\right)$. For $h>\hat{h}$, the patentholder prefers to have the small improvement instead of the large one.

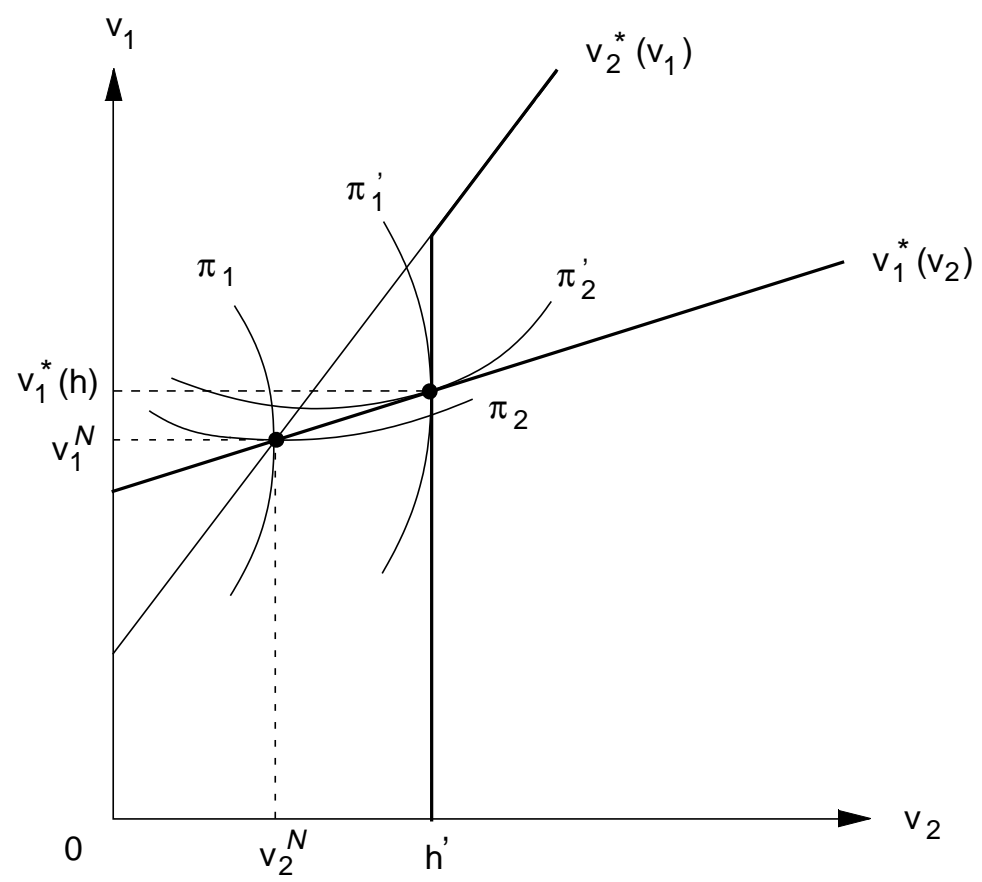

Figure 1. Patent on the Basic Invention; Firm 2 has the Small Improvement

\footnotetext{
${ }^{8}$ I restrict the analysis to one patent. I assumed that an improver cannot get a patent. Allowing for a second patent complicates matters since the basic inventor has to take into account that his strategy space might also be restricted if the improver has a patent.
} 
What happens to the profits of firm 2 when it has the small improvement? For $h<\hat{h}$, firm 2 has to deviate from its reaction function (7a) and has to choose the small improvement larger than in the basic Nash equilibrium. As a result its profits will initially increase in $h$. Profits will increase up to the height $h^{\prime}$, where $h^{\prime}$ is equal to the product improvement that firm 2 would choose it were Stackelberg leader. In figure $1, \pi_{2}{ }^{\prime}$ represents the (Stackelberg) profit level of firm 2 given patent height $h^{\prime}$. This profit level is higher than the one in the basic Nash equilibrium, $\pi_{2}$. Profits start decreasing for firm 2 from $h^{\prime}$ on. ${ }^{9}$ For $h>\hat{h}$, the patentholder does not even want the large improvement anymore and leaves it to the nonpatentholder, despite the fact that it yielded more profits in the basic Nash equilibrium. The economic intuition behind this surprising result is that patent height forms a credible commitment which the non-patentholder can exploit. Initially the non-patentholder is credibly committed to choosing a larger $\mathrm{v}_{\mathrm{S}}$ than in basic Nash equilibrium. For even higher patents $(h>\hat{h})$, the commitment becomes so strong that the non-patentholder always has the more profitable large improvement ${ }^{10}$.

\footnotetext{
${ }^{9} \mathrm{I}$ limit the analysis here to the case where $\hat{\mathrm{h}}>\mathrm{h}$ '. The maximum profits of firm 2 in the turning point do not exceed the profits with the large improvement in the basic Nash equilibrium. In the case of $\hat{h}\left\langle h^{\prime}\right.$, firm 2's profit only increases in $h$ for $h \in\left\langle v_{S}^{N}, \hat{h}\right\rangle$. If the maximum profit in the turning point $h^{\prime}$ is larger than the profit associated with the large improvement in the basic Nash equilibrium, then an extra category can be distinguished in which firm 2 prefers the small improvement $h$ and firm 1 prefers the large improvement $\mathrm{v}_{\mathrm{L}}^{*}(\mathrm{~h})$.
}

${ }^{10}$ This disadvantage for the patentholder may depend on two assumptions made above. First, the assumption that firm 1 patents immediately may be important here because, without the patent, the possibility would stay open for firm 1 to have the more profitable large improvement. As we will see below, however, from a critical protection on it is beneficial again for firm 1 to have the patent. By waiting and patenting later, the protection associated with an improvement patent becomes larger $\left(\mathrm{v}_{\mathrm{L}}\right.$ $\geq \mathrm{v}_{\mathrm{S}}+\mathrm{h}$ ). But firm 2 could then obtain the patent as well. A critical height must exist for which both firms are indifferent to having the patent or not. It could well be the case that the profits, associated with this critical height, are lower than the profits of the firm with the small improvement in the basic Nash equilibrium (e.g., if the profits associated with the restricted large improvement are lower than those associated with the patented small improvement and there is some probablility of not obtaining the patent). For these cases, firm 1 would patent immediately anyway.

Another way out of the disadvantageous patent position might be licensing. Although licensing is excluded from the present analysis, I will comment on it briefly here. Note that the patentholder has an incentive to offer, even freely, the improver a license, allowing him to choose an improvement inside the protected region. Profits of the patentholder would increase. The profits of the improver and license taker would, however, decrease. Thus, unless the patentholder is able to precommit to license its patent freely, a license contract would not emerge. And even if such precommitment is possible (e.g., if the patent office recognizes the one-sided free gift and adjusts its standards of examination, or if licensing is compulsory), the improver may be able to precommit not to accept the free gift (e.g., by provoking a court or patent office judgement). If the patentholder can precommit to license freely and the improver cannot precommit not to accept, the basic Nash equilibrium where the patentholder has the large improvement would reoccur. 
This advantage for the improver, however, disappears. From a certain height on, the commitment becomes an obligation; firm 2 must choose a larger improvement than it would like to. Higher patents then yield more profit for the patentholder and less for the nonpatentholder if the latter is also effectively restricted in the choice of the large improvement. The following proposition holds:

Proposition 1.b. For $\mathrm{h} \in\left\langle\mathrm{v}_{\mathrm{L}}{ }^{\mathrm{N}}, 1\right\rangle$ there is one Nash equilibrium with $\mathrm{v}_{1}=\mathrm{v}_{\mathrm{S}}{ }^{*}(\mathrm{~h})$ and $\mathrm{v}_{2}=\mathrm{h}$. The Nash equilibrium is characterized by (a) larger improvements than in the relevant basic Nash equilibrium; (b) an increasing profit of the patentholder in h; and (c) a decreasing profit of the non-patentholder in $\mathrm{h}$.

Firm 2 is effectively restricted in its choice of the large product improvement for the patent heights $h \in\left\langle\mathrm{v}_{\mathrm{L}}{ }^{N}, 1\right\rangle$. The choice of $\mathrm{v}_{\mathrm{L}}{ }^{N}$ is not allowed and firm 2 does best choosing $\mathrm{h}$. The best reaction of the patentholder is $\mathrm{v}_{\mathrm{S}}=\mathrm{v}_{\mathrm{S}}{ }^{*}(\mathrm{~h})$. The only Nash equilibrium is characterized by a small improvement of the patentholder of $\mathrm{v}_{1}=\mathrm{v}_{\mathrm{S}}{ }^{*}(\mathrm{~h})$ and a large improvement of firm 2 of $v_{2}=h$. Note that both improvements are larger than in the relevant basic Nash equilibrium; $\mathrm{h}>\mathrm{v}_{\mathrm{L}}{ }^{N}$ holds by definition, and $\mathrm{v}_{\mathrm{S}}{ }^{*}(\mathrm{~h})>\mathrm{v}_{\mathrm{S}}{ }^{N}$ because $\partial \mathrm{v}_{\mathrm{S}}{ }^{*} / \partial \mathrm{v}_{\mathrm{L}}>0$. In section 2 , I demonstrated that the optimal profits of the small improvement firm always increase in $v_{S}$ along the reaction curve $(7 \mathrm{~b})$. The profits of the patentholder thus increase in $\mathrm{h}$ for $\mathrm{h} \in\left\langle\mathrm{v}_{\mathrm{L}}{ }^{\mathrm{N}}\right.$, 1). What happens to the profits of the non-patentholder? He has to deviate from his reaction curve. The isoprofit curve that passes through the new Nash equilibrium now represents its lower profit level ${ }^{11}$. Hence, the profits of firm 2 decrease in $h$ for $h \in\left\langle v_{L}{ }^{N}, 1\right\rangle$. The patent height has changed for firm 2 from a profitable commitment into a profit-loosing obligation. The five categories are summarized in table 1 with the values that follow from the used specification.

\footnotetext{
${ }^{11}$ It is possible that firm 2 does not enter the market for $\mathrm{h}<1$. This is the case from that height where the isoprofit curve in the new Nash equilibrium also cuts the $45 \circ$ line with $\mathrm{v}_{\mathrm{S}}=\mathrm{v}_{\mathrm{L}}$. The profit of the entrant is zero if both product improvements are identical; it is well known that Bertrand competition with homogeneous products leads to zero profits. When lower than 1 , this critical patent height is the upper limit.
} 


\begin{tabular}{ll}
\hline \multicolumn{1}{c}{ Patent Height } & \multicolumn{1}{c}{ Nash Equilibrium } \\
\hline $\mathrm{h} \in[0,(\mathrm{q}-\mathrm{r}) /(3 \mathrm{q}-\mathrm{r})\rangle$ & $\mathrm{v}_{\mathrm{S}}{ }^{N}=(\mathrm{q}-\mathrm{r}) /(3 \mathrm{q}-\mathrm{r})$ \\
& $\mathrm{v}_{\mathrm{L}}{ }^{N}=(2 \mathrm{q}-\mathrm{r}) /(3 \mathrm{q}-\mathrm{r})$ \\
\hline $\mathrm{h} \in\left[(\mathrm{q}-\mathrm{r}) /(3 \mathrm{q}-\mathrm{r}), 1-\left(2 \sqrt{ }\left(\mathrm{q}^{3} / \mathrm{s}\right) /(3 \mathrm{q}-\mathrm{r})\right)\right]$ & $\mathrm{v}_{1}=\mathrm{v}_{\mathrm{S}}{ }^{N}=(\mathrm{q}-\mathrm{r}) /(3 \mathrm{q}-\mathrm{r})$ \\
& $\mathrm{v}_{2}=\mathrm{v}_{\mathrm{L}}{ }^{N}=(2 \mathrm{q}-\mathrm{r}) /(3 \mathrm{q}-\mathrm{r})$ \\
& $\mathrm{v}_{2}=\mathrm{v}_{\mathrm{S}}=\mathrm{h}$ \\
& $\mathrm{v}_{1}=\mathrm{v}_{\mathrm{L}}=(\mathrm{h}+1) / 2$ \\
\hline $\mathrm{h} \in\left\langle 1-\left(2 \sqrt{ }\left(\mathrm{q}^{3} / \mathrm{s}\right) /(3 \mathrm{q}-\mathrm{r})\right),(2 \mathrm{q}-\mathrm{r}) /(3 \mathrm{q}-\mathrm{r})\right]$ & $\mathrm{v}_{1}=\mathrm{v}_{\mathrm{S}}{ }^{N}=(\mathrm{q}-\mathrm{r}) /(3 \mathrm{q}-\mathrm{r})$ \\
& $\mathrm{v}_{2}=\mathrm{v}_{\mathrm{L}}{ }^{N}=(2 \mathrm{q}-\mathrm{r}) /(3 \mathrm{q}-\mathrm{r})$ \\
\hline $\mathrm{h} \in\langle(2 \mathrm{q}-\mathrm{r}) /(3 \mathrm{q}-\mathrm{r}), 1\rangle$ & $\mathrm{v}_{1}=\mathrm{v}_{\mathrm{S}}=(\mathrm{h}(\mathrm{r}+\mathrm{q})-\mathrm{r}) / 2 \mathrm{q}$ \\
& $\mathrm{v}_{2}=\mathrm{v}_{\mathrm{L}}=\mathrm{h}$ \\
\hline $\mathrm{h} \in[1, \infty\rangle$ & $\mathrm{v}_{1}=1 / 2$ \\
\hline
\end{tabular}

Table 1. Effects of Patent Height with a Patent on the Basic Invention

\subsection{Perfect Secrecy of the Basic Invention}

The scenario described above is an asymmetric variant of the model of Ronnen (1991) and Crampes and Hollander (1991) on minimum quality standards. The secrecy scenario is specific to a context of technical progress and patent protection. If firm 1 can keep its basic invention perfectly secret, it will not patent immediately. By waiting and patenting just before introduction, the patentholder enlarges the protection of his patent, as will be shown below. Price competition remains unchanged compared to section 2. The competition in product improvements is now as follows. Firm 1 makes its choice of $v_{1}$ in the starting period. Just before the introduction in period $\mathrm{T}_{1}\left(\mathrm{v}_{1}\right)$ it takes a patent on the improvement $\mathrm{v}_{1}$ and obtains protection of $\left[0, \mathrm{v}_{1}+\mathrm{h}\right] .^{12}$ The lower limit is 0 because firm 2 will never be allowed to enter with a deterioration. The upper limit is determined by the fact that the patent office requires that $h$ is the minimal inventive step of improvement of the patented improvement $v_{1}$. As soon as firm 1 applies for a patent and enters the market, firm 2 chooses its improvement. Since the information in the patent is public, firm 2 starts from the knowledge level revealed in the patent application. The strategy space of firm 2 is $v_{2} \in\left\langle v_{1}+h, 1\right]$. A consequense of this structure is that firm 1 will always have the small improvement and firm 2 the large improvement $\left(v_{1} \leq v_{2}\right)$. A major advantage for firm 1 is that it can make its choice before firm 2. Instead of a Nash equilibrium, the relevant equilibrium concept is therefore a Stackelberg

\footnotetext{
${ }^{12}$ I assume that firm 1 patents the largest improvement available at that time as to rule out the possibility that it takes a patent on the basic invention, while having generated an improvement, in order to be able to have the larger improvement in equilibrium.
} 
equilibrium, with firm 1 being the leader and firm 2 the follower. The basic Stackelberg equilibrium in improvements is denoted by $\left\{\mathrm{v}_{1}{ }^{S}, \mathrm{v}_{2}{ }^{S}\right\}$. The three categories of patent heights in the scenario of Stackelberg leadership are summarized in table 2. Each category will be explained below.

\begin{tabular}{ll}
\hline \multicolumn{1}{c}{ Patent Height } & \multicolumn{1}{c}{ Stackelberg Equilibrium } \\
\hline $\mathrm{h} \in[0,(\sqrt{ }(2 \mathrm{q}-\mathrm{r})-\sqrt{ }(\mathrm{q}-\mathrm{r})) / 2 \sqrt{ }(2 \mathrm{q}-\mathrm{r})\rangle$ & $\mathrm{v}_{1}{ }^{S}=(\mathrm{q}-\mathrm{r}) /(2 \mathrm{q}-\mathrm{r})$ \\
& $\mathrm{v}_{2}{ }^{S}=(3 \mathrm{q}-2 \mathrm{r}) / 2(2 \mathrm{q}-\mathrm{r})$ \\
\hline $\mathrm{h} \in[(\sqrt{ }(2 \mathrm{q}-\mathrm{r})-\sqrt{ }(\mathrm{q}-\mathrm{r})) / 2 \sqrt{ }(2 \mathrm{q}-\mathrm{r}), 1 / 2]$ & $\mathrm{v}_{1}{ }^{\mathrm{B}}=1-\mathrm{h}$ \\
\hline $\mathrm{h} \in\langle 1 / 2, \infty\rangle$ & $\mathrm{v}_{1}{ }^{\mathrm{M}}=1 / 2$ \\
\hline
\end{tabular}

Table 2. Effects of Patent Height in the case of Secrecy of the Basic Invention

In order to find the basic Stackelberg equilibrium, I first determine the reaction function of firm 2 in this scenario:

$$
\mathrm{v}_{2}^{*}\left(\mathrm{v}_{1}\right)=\max \left(\left(\mathrm{v}_{1}+1\right) / 2 ; \mathrm{v}_{1}+\mathrm{h}\right)
$$

The unrestricted part of the reaction function can be used to establish the basic Stackelberg equilibrium as $v_{1}{ }^{S}=(q-r) /(2 q-r)$ and $v_{2}{ }^{S}=(3 q-2 r) / 2(2 q-r)$. This Stackelberg equilibrium is depicted in figure 2 and, as will be shown below, is only relevant to low patent heights.

The Stackelberg equilibrium for the restricted part, $\mathrm{v}_{2}=\mathrm{v}_{1}+\mathrm{h}$, turns out to be undetermined because the profits of firm 1 always increase in $v_{1}$, independent of height $h$. In order to be able to determine which improvement(s) will appear on the market, I define $\mathrm{v}_{1}{ }^{\mathrm{B}}$ as the improvement that blockades the market for firm 2. This means that firm 2's strategy space in improvements is empty (firm 2 will not enter). The blockading improvement here is $\mathrm{v}_{1}{ }^{\mathrm{B}}$ $=1-\mathrm{h}$. Let the optimal improvement choice of a monopolist be denoted by $\mathrm{v}_{1}{ }^{\mathrm{M}}$. If the monopoly improvement is larger than the blockading improvement $\left(\mathrm{v}_{1}{ }^{\mathrm{M}} \geq \mathrm{v}_{1}{ }^{\mathrm{B}}\right)$, firm 1 is better off choosing the monopoly improvement because this also blockades the market and is optimal by definition. Additionally, if the monopoly profit of firm 1 is larger than its Stackelberg profit, which is the case here, the upper category is established. For $h \in\langle 1 / 2, \infty\rangle$, firm 1 will be a pure monopolist until doomsday with a product improvement of $\mathrm{v}_{1}{ }^{\mathrm{M}}=1 / 2$. For $\mathrm{v}_{1}{ }^{\mathrm{M}} \leq \mathrm{v}_{1}{ }^{\mathrm{B}}$, firm 1 cannot choose the monopoly improvement because firm 2 would then 


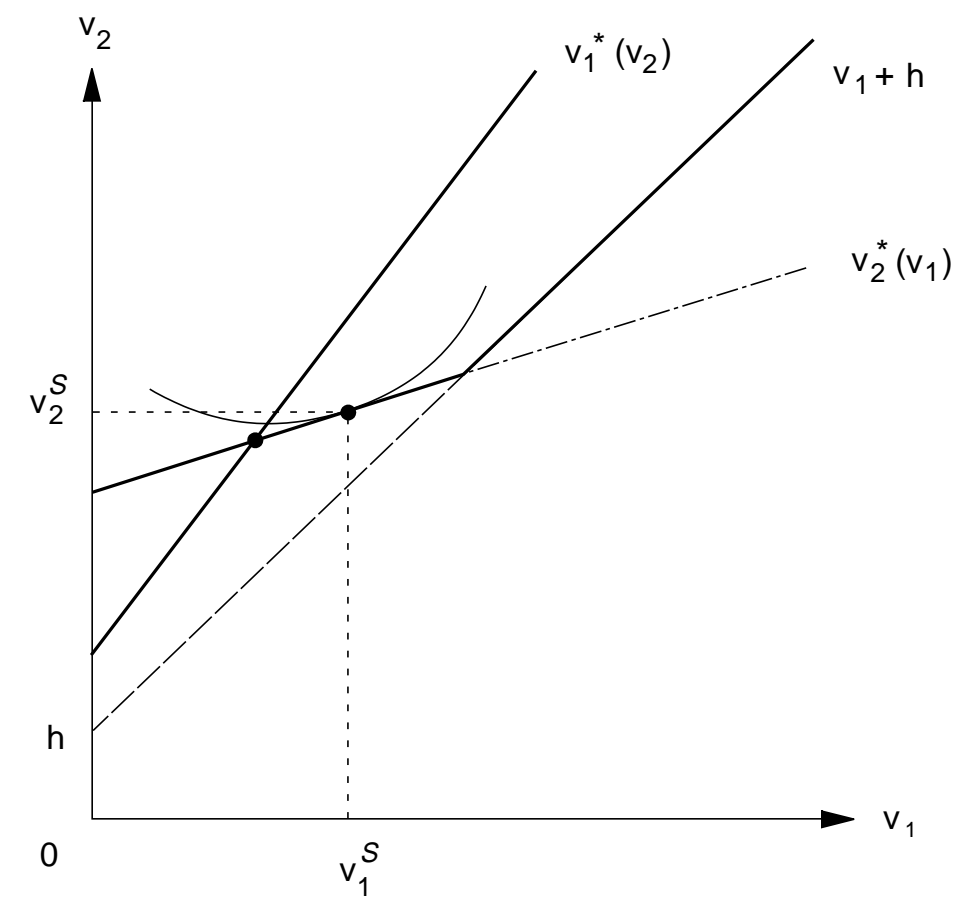

Figure 2. Patent on the First Improvement

enter. Instead, firm 1 chooses the blockading improvement. Compared to the optimal monopoly profits, the blockading profits decrease if $\mathrm{v}_{1}{ }^{\mathrm{B}}$ is further away from $\mathrm{v}_{1}{ }^{\mathrm{M}}$, i.e., when patents are lower. The loss in profits due to the strategy of market blockade becomes large to the extent that, from a critical patent height on, firm 1 is better off being a Stackelberg leader in duopoly than a blockading monopolist. Label this height as $h "$, defined as $\pi_{1}\left(1-h^{\prime \prime}\right)$ $\equiv \pi_{1}^{S}\left(\mathrm{v}_{1}{ }^{S}, \mathrm{v}_{2}{ }^{S}\right)$. The two remaining categories can now be determined. For $\mathrm{h} \in[\mathrm{h} ", 1 / 2]$, firm 1 will be a blockading monopolist until doomsday with the blockading improvement $\mathrm{v}_{1}{ }^{\mathrm{B}}=$ 1 - h. ${ }^{13}$ For $\mathrm{h} \in[0, \mathrm{~h} "\rangle$, firm 1 will be Stackelberg leader in duopoly. Proposition 2 summarizes the three categories of patent heights.

Proposition 2. For $\mathrm{h} \in[0, \mathrm{~h} "\rangle$ the improvements developed in the Stackelberg equilibrium are $\mathrm{v}_{1}{ }^{S}$ and $\mathrm{v}_{2}{ }^{S}$. For $\mathrm{h} \in\left[\mathrm{h}^{\prime \prime}, 1 / 2\right]$ the patentholder is a blockading monopolist with an improvement of $\mathrm{v}_{1}{ }^{\mathrm{B}}=1-\mathrm{h}$; the profits of the patentholder increase in $\mathrm{h}$ until monopoly profits are reached for $h=1 / 2$. The patentholder continues to be a monopolist for $h \in\langle 1 / 2$, $\infty)$ with an improvement of $\mathrm{v}_{1}{ }^{\mathrm{M}}=1 / 2$.

\footnotetext{
${ }^{13}$ The critical height $\mathrm{h}$ " in the used specification is not larger than the natural distance between the small and the large improvement in the basic Stackelberg equilibrium $\left(\mathrm{h}^{\prime \prime} \leq \mathrm{v}_{2}{ }^{S}-\mathrm{v}_{1}{ }^{S}\right)$. The third category, for low patents, then is $\mathrm{h} \in\left[0, \mathrm{~h}^{\prime \prime}\right\rangle$. Firm 1 will first come up with $\mathrm{v}_{1}{ }^{S}$. Afterwards, firm 2 follows with $\mathrm{v}_{2}{ }^{S}$.
} 


\subsection{Patent Height and Welfare}

The static welfare in the market can be determined in a simple manner because of the linear demand structures resulting from utility function (1). The sum of consumer and producer surplus can be taken as an approximation for the total welfare. A product improvement generates a level of welfare equal to $3 / 2$ of the total profit, both under monopoly and under duopoly. Maximization of welfare is thus equivalent to maximization of joint profits. It can easily be shown that with a patent on the basic invention (scenario [1]), the optimal patent height from a social point of view is given by $\left.h^{*}=(r+s) /(2 s-q+r)\right)$ inside the category $h$ $\in\left\langle\mathrm{v}_{\mathrm{L}}{ }^{N}, 1\right\rangle$ in which the Nash equilibrium with $\mathrm{v}_{\mathrm{S}}=\mathrm{v}_{\mathrm{S}}{ }^{*}(\mathrm{~h})$ and $\mathrm{v}_{\mathrm{L}}=\mathrm{h}$ occurs. All heights in the category $\left[0, h^{\prime \prime}\right\rangle$ where a Stackelberg equilibrium with $\mathrm{v}_{1}{ }^{S}$ and $\mathrm{v}_{2}{ }^{S}$ occurs are socially optimal in scenario [2].

These welfare conclusions are concerned with the static efficiency once the basic invention is generated. However, a more complete welfare analysis in the context of technical progress would take into account the necessity of an incentive for research. The presence of a basic invention as a starting point is appropriate for competition analysis but not for welfare analysis. How can this research incentive be taken into account? In Klemperer (1990) and Gilbert en Shapiro (1990), it is introduced in the form of a minimial profit V for the firm that undertakes R\&D. In the underlying case of patent height, the question raises which firm, 1 or 2, is to be given the incentive V. After all, both firms carry out R\&D. In a very specific sense, the profits of the patentholder and the improver stand for special incentives. If the patent office wants to induce basic research, it would make the profit of the patentholder equal to $\mathrm{V}$. The patentholder's profits, namely, represent the possible gains from basic research, which is, rather limited, defined here as research that has no direct links with previous research. When patenting the products of basic research, the inventor does not have to take into consideration the minimal steps of improvement. Therefore, if the novelty requirements are more stringent, he only benefits because more protection is provided. He does not face the disadvantage of higher patents, which are harder to overcome. Applied research and development could be defined as research that builds more on previous research. It is in this specific sense that the non-patentholder's profits represent the gains from applied research and development. If the patent office therefore wants to promote applied research and development, it should set the height such that the non-patentholder obtains profit $\mathrm{V}$. Depending on the size of $\mathrm{V}$, the optimal height can thus be in any category. 


\section{Conclusions}

This paper has shown that the height of patent protection as determined by the stringency of novelty requirements can affect the competition in product improvements. Low patent protection does not affect the natural market equilibrium in product improvements. This result holds regardless of whether or not the basic invention can be kept secret. In the scenario with perfect secrecy the inventor can already obtain a monopoly position with medium-height patents. If secrecy is impossible, the medium category of patent heights is unfavourable to the patentholder since the improver can commit credibly to the more profitable strategy. High patents are again favourable to the patentholder. His profits then increase in height, even up to the monopoly level. It should be stressed that these conclusions are only valid under a set of simplifying assumptions which might be restrictive.

Because of the limitations of the model, some possible applications can only be given with great care. First, it is an empirical fact that firms do not patent all their inventions (e.g. Scherer (1983)). Because low patents do not affect competition, the application costs could be sufficient reason not to patent. Second, in the specific sense explained above, the model might also apply to technology policy. Patent height can be used as an instrument to give relative weights to incentives for basic research vis-á-vis applied research and development ${ }^{14}$. There is a trend in Europe towards uniform patent heights. ${ }^{15}$ Suppose that the uniform patent height of the European Patent System will be the mean of national patent heights. The model predicts that uniform patent height has different effects on individual countries. Countries with high novelty requirements, such as Germany for example, are expected to shift from

\footnotetext{
${ }^{14}$ The emphasis on basic or applied research can be found in national patent policies. Japan, for example, could be considered to have a comparative advantage in applied research and product improvements. Patent protection in Japan is rather low in the sense that each separate claim can be patented (Ordover (1991)). It would be premature to conclude that there is a causal relation between low patents and advantage in improvements in Japan, but the co-existence is not illogical. The US and Germany, both countries that can be considered to have a comparative advantage in basic research, have relatively high patents (Ordover (1991)).

${ }^{15}$ In the light of the general aim to integrate European countries, the European Community has since the early days tried to unify and integrate national patent systems. The first attempt for unification was the Treaty of Strassbourg in 1963. Countries were obliged to conform parts of their national patent laws to statements of the treaty. Although the treaty itself was held in 1963, it was not made operative until 1980. The second step towards a common patent was taken in 1973 with the European Patent Convention (EPC) in Munich. A European patent is centrally granted by the European Patent Office in Munich, but subject to national patent laws. A firm must choose the EPCconnected countries for which the European patent is applied. The EPC came to work for most countries in 1980. The logical next step in fulfilling the aim for integration is to design a common European patent that holds for all European countries and is subject to a common European patent law. This step was taken in the Community Patent Convention of 1975, but is not operative yet.
} 
basic research towards applied research. Countries with low novelty requirements, like for example Portugal, are expected to shift towards basic research.

At least two lines of possible extensions of the present analysis seem interesting. The first one is the incorporation of the stages before the current starting point, the presence of a basic invention. Two extra stages can be distinguished: the stage of basic R\&D and the stage of patenting behavior. A basic R\&D race is not a winner-takes-all game in the present model, as opposed to many other models. Patent height can affect the degree of R\&D spending of both firms. The patenting decision can also be endogenized, like in Scotchmer and Green (1990), allowing one to explain which invention is patented when. Another possible extension concerns the number of innovations and patents. More than two patentable improvements can occur over time. The larger improvement can then become the smaller improvement in the next period. This would make the analysis more dynamic.

\section{References}

Cohen, W. and Levinthal D. (1989). "Innovation and Learning: The Two Faces of R\&D" Economic Journal 99, 569-596.

Cornish, W.R. (1989). Intellectual Property: Patents, Copyright, Trade Marks and Allied Rights. Sweet \& Maxwell, London.

Crampes, C. and Hollander A. (1991). "Duopoly and Quality Standards", Discussion Paper, GREMAQ, Université des Sciences Sociales, Toulouse.

Eaton, B.C. and Lipsey, R.G. (1989). "Product Differentiation", in: R. Schmalensee, R. Willig (eds.), Handbook of Industrial Organization, Elsevier, Amsterdam.

Gilbert, R. and Shapiro, C. (1990). "Optimal Patent Length and Breadth", RAND Journal of Economics, 21, 106-112.

Griliches, Z. (1990). "Patent Statistics as Economic Indicators: A Survey", Journal of Economic Literature, XXVIII, 1661-1707. 
Hotelling, H. (1929). "Stability in Competition." Economic Journal 39, 41-57.

Klemperer, P. (1990). "How Broad should the Scope of Patent Protection Be?", RAND Journal of Economics, 21, 113-130.

Levin, R.C., Klevorick, A.K., Nelson, R.R., and Winter, S.G. (1987). "Appropriating the Returns from Industrial Research and Development", Brookings Papers on Economic Activity, 3, 783-820.

Mansfield, E., Schwartz, M. and Wagner, S. (1981), "Imitation Costs and Patents: An Empirical Study", Economic Journal 91, 907-918.

Nordhaus, W.D. (1969). Invention, Growth, and Welfare, A Theoretical Treatment of Technological Change. MIT Press, Cambridge.

Ordover, J.A. (1991). "A Patent System for Both Diffusion and Exclusion", Journal of Economic Perspectives, 5, 43-60.

Ronnen, U. (1991). "Minimum Quality Standards, Fixed Costs, and Competition", RAND Journal of Economics, 22, 490-504.

Scherer, F.M. (1983). "The Propensity to Patent", International Journal of Industrial Organisation, $1,107-128$.

Scotchmer, S. and Green, J. (1990). "Novelty and Disclosure in Patent Law", RAND Journal of Economics, 21, 131-146.

Shaked, A. and Sutton, J. (1982). "Relaxing Price Competition through Product Differentiation", Review of Economic Studies, 49, 3-13.

Tirole, J. (1988). The Theory of Industrial Organization. MIT Press, Cambridge.

Van Dijk, T.W. 1993. "On the Exploitation of Patent Protection", MERIT Research Memorandum 93-006, Maastricht.

Waterson, M. (1990). "The Economics of Product Patents", American Economic Review, 80, 860869. 